\title{
Serum Adiponectin Concentrations in Newborn Infants in Early Postnatal Life
}

\author{
TOMOHIRO KAMODA, HISAKO SAITOH, MAKOTO SAITO, MASATOSHI SUGIURA, AND \\ AKIRA MATSUI
}

Department of Pediatrics, University of Tsukuba, Ibaraki, Japan

\begin{abstract}
ABST
Serum adiponectin levels were investigated in 28 small-for-
gestational-age (SGA) and 34 appropriate-for-gestational-age
(AGA) term neonates to examine how fetal growth correlates
with adiponectin levels. A blood sample for determination of
adiponectin was obtained during the first 24 h of life. The levels
of serum adiponectin were significantly higher in all newborn
infants than in healthy children $(28.7 \pm 17.0$ versus $9.3 \pm 6.1$
$\mu$ g/mL; $p<0.01)$. There was a significant difference in adi-
ponectin levels between SGA and AGA infants $(23.2 \pm 14.8$
versus $33.2 \pm 17.5 \mu$ g/mL; $p=0.02)$. For all of the newborn
groups, serum adiponectin levels correlated positively with birth
weight $(r=0.27, p<0.05)$ and head circumference $(r=0.30$,
$p<0.05)$. There was no relationship between serum adiponectin
levels and gestational age, birth length, blood glucose levels, or
blood sampling time after birth. There was no gender difference
\end{abstract}
in adiponectin levels in the entire newborn group $(30.0 \pm 19.7$ versus $28.0 \pm 15.5 \mu \mathrm{g} / \mathrm{mL}$, in male and female infants). Our results suggest that hyperadiponectinemia and a positive relationship between the serum levels of adiponectin and birth weight in newborns cannot be explained by the low percentage of body fat alone. Lower adiponectin levels in SGA infants than in AGA infants are unlikely to suggest insulin resistance in intrauterine growth-retarded infants in early postnatal life but may be a predisposing factor in the future development of insulin resistance or type 2 diabetes. (Pediatr Res 56: 690-693, 2004)

\section{Abbreviations}

AGA, appropriate for gestational age

BAT, brown adipose tissue

SGA, small for gestational age
Adiponectin is a protein derived from adipose tissue in humans, and serum adiponectin levels are paradoxically reduced in obese individuals (1). Decreased concentrations of adiponectin are also seen in patients with insulin resistance or type 2 diabetes (2). Insulin-sensitizing agents such as thiazolidinediones increase adiponectin concentrations in humans (3) and in animals (4), whereas administration of adiponectin increases insulin sensitivity in animals (4). However, intrauterine growth retardation is associated with an increased risk of developing type 2 diabetes and cardiovascular disease $(5,6)$. To explain this association, the concept of "reprogramming" was introduced (7): fetal adaptation to an adverse intrauterine environment determines an altered programming of endocrine pathways, leading to permanent metabolic changes, including insulin resistance. The present study was undertaken to examine how different intrauterine growth patterns relate to adiponectin secretion in early neonatal life.

Received March 23, 2004; accepted June 28, 2004

Correspondence: Tomohiro Kamoda, M.D., Department of Pediatrics, University of Tsukuba, 1-1-1 Tennoudai, Tsukuba 305-8575, Ibaraki, Japan; e-mail: tkamoda@ md.tsukuba.ac.jp

DOI: 10.1203/01.PDR.0000142711.24999.8A

\section{METHODS}

Infants. Thirty-four newborns (20 boys and 14 girls) with appropriate-for-gestational-age (AGA) birth weight (relative birth weight below +2 or above -2 SD) and 28 (16 boys and 12 girls) with small-for-gestational-age (SGA) birth weight (relative birth weight, -2 or less SD) were included in the study (Table 1). All neonates had no asphyxia at birth and were found to be well on physical examination performed at the time of blood sampling. All infants in both groups were breast-fed, with similar frequencies ranging from 3 to $4 \mathrm{~h}$. A blood sample was obtained from each infant immediately before feeding. Serum was separated immediately by centrifugation and kept at $-20^{\circ} \mathrm{C}$ until analysis. Sixteen control children (12 boys and 4 girls; $10.1 \pm 0.7 \mathrm{y}$, mean $\pm \mathrm{SD}$ ) were selected from the infants who visited the pediatric clinic because of nonendocrinologic problems. The control children all were free of clinically or biochemically apparent disease and were not taking any medication. Blood samples were collected from control subjects in the fasting state. Informed consent was obtained from the parents of all of the children, and the study was approved by the local ethics committee.

Measurements. The serum adiponectin concentration was assayed with an RIA kit (HADP-61HK, Linco Research, Inc., St. Charles, MO). The sensitivity of the assay was $1 \mu \mathrm{g} / \mathrm{mL}$, 
Table 1. Characteristics and serum glucose and adiponectine levels in $A G A$ and SGA infants

\begin{tabular}{lccc}
\hline & $\begin{array}{c}\text { AGA } \\
(n=34)\end{array}$ & $\begin{array}{c}\text { SGA } \\
(n=28)\end{array}$ & $p$ values \\
\hline Gestational age (wk) & $39.3 \pm 1.2$ & $38.7 \pm 1.1$ & 0.06 \\
Birth weight $(\mathrm{kg})$ & $2.93 \pm 0.23$ & $2.35 \pm 0.17$ & $<0.001$ \\
Birth length $(\mathrm{cm})$ & $48.2 \pm 1.2$ & $45.3 \pm 1.6$ & $<0.001$ \\
Birth head circumference $(\mathrm{cm})$ & $33.2 \pm 1.2$ & $32.1 \pm 0.9$ & $<0.001$ \\
Sampling time (h after birth) & $6.0 \pm 6.0$ & $6.6 \pm 6.7$ & NS \\
Serum glucose $(\mathrm{mg} / \mathrm{dL})$ & $50.7 \pm 14.8$ & $56.8 \pm 30.1$ & $\mathrm{NS}$ \\
Serum adiponectin $(\mu \mathrm{g} / \mathrm{mL})$ & $33.2 \pm 17.5$ & $23.2 \pm 14.8$ & 0.02 \\
\hline
\end{tabular}

Values are mean \pm SD. NS, not significant.

and the limit of linearity was $250 \mu \mathrm{g} / \mathrm{mL}$. Inter- and intra-assay coefficients of variation were $6.9-9.3 \%$ and $1.8-6.2 \%$, respectively. Blood glucose concentration was determined using a commercial glucometer (Antsense II, Bayer-Sankyo Co., Tokyo, Japan).

Statistical methods. The results are expressed as the mean \pm SD unless otherwise stated. The unpaired $t$ test or the MannWhitney $U$ test was used to determine statistical significance. Differences in infant characteristics were determined by oneway ANOVA, with gender as a class variable. Analysis of covariance was performed to assess the contribution of birth weight to the difference in serum adiponectin levels between SGA and AGA groups. Relationships between parameters were evaluated by simple linear regression analysis. All analyses were performed using StatView 5.0 (SAS Institute, Inc., Cary, NC). A level of $p<0.05$ was accepted as statistically significant.

\section{RESULTS}

Infant characteristics and the levels of serum adiponectin and blood glucose are shown in Table 1. All newborn infants were born at full term (gestational age $>37$ wk) with uneventful vaginal delivery. The AGA and SGA infants were comparable in terms of gestational age, blood glucose concentrations, and blood sampling time after birth. Predictably, SGA infants had shorter birth length and smaller head circumference and were lighter in birth weight than AGA neonates. The levels of serum adiponectin were significantly higher in all newborn infants than in control children $(28.7 \pm 17.0$ versus $9.3 \pm 6.1$ $\mu \mathrm{g} / \mathrm{mL} ; p<0.01)$. There was no gender difference in adiponectin levels between male and female newborn infants in the entire newborn group $(30.0 \pm 19.7$ versus $28.0 \pm 15.5$ $\mu \mathrm{g} / \mathrm{mL}$ ). The levels of serum adiponectin in SGA infants were significantly lower than in AGA infants $(23.2 \pm 14.8$ versus $33.2 \pm 17.5 \mu \mathrm{g} / \mathrm{mL} ; p=0.019)$. The differences observed in adiponectin between SGA and AGA infants similarly persisted after adjustment for gender $(p=0.021)$ or birth weight $(p=$ 0.018 ). For all of the newborn groups, serum adiponectin levels correlated positively with birth weight $(r=0.27, p<0.05$; Fig. 1) and head circumference $(r=0.30, p<0.05)$. There was no relationship between serum adiponectin levels and gestational age, birth length, blood glucose concentrations, or blood sampling time after birth.

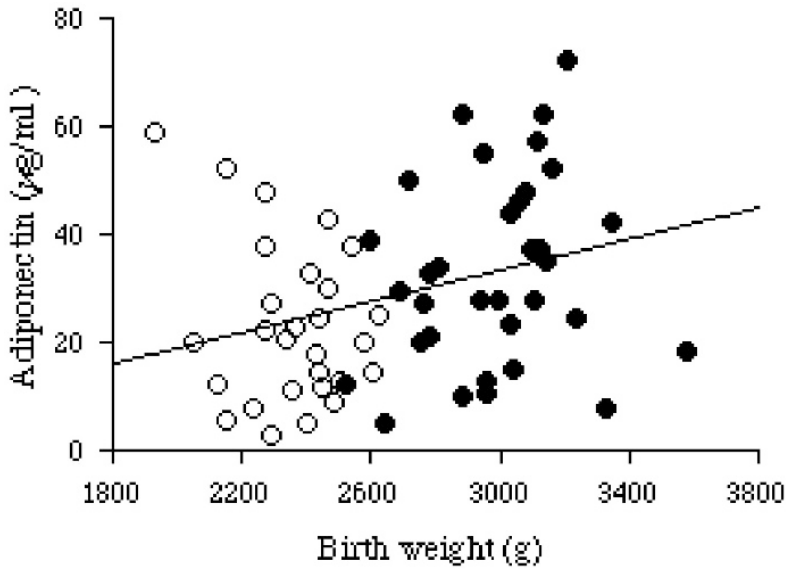

Figure 1. Relationship between the serum adiponectin levels and birth weight in AGA (O) and SGA $(\bigcirc)$ infants $(r=0.27, p<0.05)$.

\section{DISCUSSION}

The exact role of adiponectin in regulating intrauterine fetal growth has not been fully elucidated. Only a few studies have shown that the circulating adiponectin concentration in cord blood is higher than that in adults $(8-10)$. The mean level of serum adiponectin in our AGA infants during the first $24 \mathrm{~h}$ of life was lower than that of cord blood adiponectin reported by Sivan et al. (8) or Chan et al. (10) but was higher than that of cord blood adiponectin reported by Lindsay et al. (9), despite that these different researchers used the same assay kit and that the infants were comparable with regard to mean gestational age and birth weight in each study. Regarding the change of the serum adiponectin concentration after birth, Sivan et al. (8) reported that when comparing adiponectin levels at birth and the fourth day postdelivery, no decline in adiponectin was observed. Thus, it was considered that the adiponectin levels in our study were not influenced by the blood sampling time during at least the first $24 \mathrm{~h}$ of life. The discrepancies between our results and those of other researchers may be related to differences in sample selection or size. Adiponectin levels were found to be gender dependent in adults, with women having higher concentrations of circulating adiponectin than men $(1,11)$. We compared the levels of adiponectin between female and male neonates in the entire group but found no differences in adiponectin levels between the genders. The difference between the genders in adults may reflect an effect of the sex hormones $(12,13)$ or other mediators that are inactive, subtle, or absent in newborns (8).

In our study, the levels of serum adiponectin were significantly higher in newborn infants than in control children and were correlated positively with birth weight in all newborn infants. Although the former result may be partly explained by the fact that the percentage of body fat is significantly lower in newborns (13\%) than in children or adults (25-30\%) (14), the latter is not consistent with the previously reported findings that adiponectin levels are inversely correlated with body fat mass in children or adults $(1,15,16)$. A significant positive relationship has been observed between birth weight and body fat mass in newborn infants (17). There are several possible explanations for the conflicting findings. Sivan et al. (8) re- 
ported that the adiponectin levels in cord blood are extremely high compared with those in adults and are correlated positively with birth weight, assuming that the high adiponectin levels in newborns may be due to a lack of negative feedback on adiponectin production resulting from a lack of adipocyte hypertrophy, a low percentage of body fat, or a different distribution of fat depots in newborns. Viengchareun et al. (18) reported that the adiponectin gene was found to express highly in the brown adipose tissue (BAT) in rats and mice, demonstrating that brown adipocytes are endocrine cells that are capable of expressing adiponectin. Because human neonates possess a relatively higher content of BAT than do children or adults, the adiponectin secreted from BAT may contribute to the hyperadiponectinemia in newborns. The lower adiponectin levels in SGA infants than in AGA infants may be due to the presence of a lower amount of BAT in SGA infants (19). In contrast, Lindsay et al. (9) reported that adiponectin levels in cord blood are unrelated to the degree of adiposity in term infants, indicating that cord adiponectin concentrations may be influenced by multiple factors, such as insulin, proinsulin, leptin, glucocorticoid, visceral fat distribution, or maternal adiponectin levels. In our study, a difference in adiponectin levels between SGA and AGA infants remains to be significant after adjustment for birth weight, and only $7 \%$ of variation in adiponectin levels in all infants can be explained by birth weight, suggesting that other factors than birth weight as described by Lindsay et al. may contribute to adiponectin levels in neonates. Although there was no relationship between serum adiponectin levels and gestational age in our term infants, further studies are needed in infants who are born at varying gestational ages, including preterm infants, to clarify the contribution of gestational age to serum adiponectin levels in early postnatal life.

Epidemiologic studies have revealed that there is a relationship between fetal growth retardation and the subsequent development of insulin resistance and type 2 diabetes $(5,6)$. SGA infants who fail to demonstrate catch-up growth are at an increased risk for developing insulin resistance and cardiovascular disease in later life (20). However, human cross-sectional studies have shown that plasma adiponectin levels are negatively correlated with hyperinsulinemia and insulin resistance (2). Case-control studies have also demonstrated that low plasma adiponectin is an independent risk factor for future development of type 2 diabetes $(21,22)$. Although the serum levels of insulin were not determined in our study, the insulin levels in SGA newborns have been found to be low both in the cord blood and in the early postnatal period (23-25). In addition, Bazaes et al. (26) demonstrated that SGA infants display an increased peripheral insulin sensitivity with respect to glucose disposal but not with respect to suppression of lipolysis and ketogenesis and hepatic production of IGF binding protein 1 in early postnatal life. Thus, the presence of lower adiponectin levels observed in our SGA than in AGA infants is unlikely to be consistent with the fact that SGA infants have lower insulin levels and higher insulin sensitivity compared with AGA infants in early postnatal life but may be a predisposing factor in the future development of insulin resistance or type 2 diabetes. Alternatively, the lower levels of adiponectin in SGA infants may suggest the very early development of insulin resistance, as recently suggested in neonatal rats (27), in older children born SGA (28), and in adults born SGA (29). Indeed, a 2-y follow-up study in a Japanese population has shown that the baseline adiponectin level is negatively correlated with subsequent changes in insulin and the insulin resistance index, even after adjustment for change in body mass index, suggesting that the serum adiponectin concentration predicts subsequent changes in insulin resistance (30). Recently Cianfarani et al. (31) reported that serum adiponectin levels are lower in children who are born SGA (mean age, 8.6 $\pm 3.5 \mathrm{y}$ ) than in short-normal children who are born with a birth weight AGA and obese children. Although sample selection and size are different between our study and Cianfarani's, it is likely that SGA children have had low adiponectin levels since birth. Our findings provide additional evidence for the link between adverse perinatal events and the risk of metabolic sequelae in adult life.

\section{CONCLUSION}

In conclusion, the present study suggests that hyperadiponectinemia and a positive relationship between the serum levels of adiponectin and birth weight in newborns cannot be explained by the low percentage of body fat alone. The lower adiponectin levels in SGA than in AGA infants in early neonatal life may be associated with future development of insulin resistance or type 2 diabetes.

\section{REFERENCES}

1. Arita Y, Kihara S, Ouchi N, Takahashi M, Maeda K, Miyagawa J, Hotta K, Shimomura I, Nakamura T, Miyaoka K, Kuriyama H, Nishida M, Yamashita S, Okubo K, Matsubara K, Muraguchi M, Ohmoto Y, Funahashi T, Matsuzawa Y 1999 Paradoxical decrease of an adipose-specific protein, adiponectin, in obesity. Biochem Biophys Res Commun 257:79-83

2. Weyer C, Funahashi T, Tanaka S, Hotta K, Matsuzawa Y, Pratley RE, Tataranni PA 2001 Hypoadiponectinemia in obesity and type 2 diabetes: close association with insulin resistance and hyperinsulinemia. J Clin Endocrinol Metab 86:1930-1935

3. Maeda N, Takahashi M, Funahashi T, Kihara S, Nishizawa H, Kishida K, Nagaretani H, Matsuda M, Komuro R, Ouchi N, Kuriyama H, Hotta K, Nakamura T, Shimomura I, Matsuzawa Y 2001 PPAR $\gamma$ ligands increase expression and plasma concentrations of adiponectin, an adipose-derived protein. Diabetes 50:2094-2099

4. Yamauchi T, Kamon J, Waki H, Terauchi Y, Kubota N, Hara K, Mori Y, Ide T, Murakami K, Tsuboyama-Kasaoka N, Ezaki O, Akanuma Y, Gavrilova O, Vinson C, Reitman ML, Kagechika H, Shudo K, Yoda M, Nakano Y, Tobe K, Nagai R, Kimura S, Tomita M, Froguel P, Kadowaki T 2001 The fat-derived hormone adiponectin reverses insulin resistance associated with both lipoatrophy and obesity. Nat Med 7:941-946

5. Barker DJ, Winter PD, Osmond C, Margetts B, Simmonds SJ 1989 Weight in infancy and death from ischemic heart disease. Lancet 2:577-580

6. Barker DJ, Hales CN, Fall CH, Osmond C, Phipps K, Clark PM 1993 Type 2 (non-insulin-dependent) diabetes mellitus, hypertension and hyperlipidemia (syndrome X): relation to reduced fetal growth. Diabetologia 36:62-67

7. Fall CH, Pandit AN, Law CM, Yajnik CS, Clark PM, Breier B, Osmond C, Shiell AW, Gluckman PD, Barker DJ 1995 Size at birth and plasma insulin-like growth factor-1 concentrations. Arch Dis Child 73:287-293

8. Sivan E, Mazaki-Tovi S, Pariente C, Efraty Y, Schiff E, Hemi R, Kanety H 2003 Adiponectin in human cord blood: relation to fetal birth weight and gender. J Clin Endocrinol Metab 88:5656-5660

9. Lindsay RS, Walker JD, Havel PJ, Hamilton BA, Calder AA, Johnstone FD; Scottish Multicentre Study of Diabetes Pregnancy 2003 Adiponectin is present in cord blood but is unrelated to birth weight. Diabetes Care 26:2244-2249

10. Chan TF, Yuan SS, Chen HS, Guu CF, Wu LC, Yeh YT, Chung YF, Jong SB, Su JH 2004 Correlations between umbilical and maternal serum adiponectin levels and neonatal birthweights. Acta Obstet Gynecol Scand 83:165-169

11. Yannakoulia M, Yiannakouris N, Bluher S, Matalas AL, Klimis-Zacas D, Mantzoros CS 2003 Body fat mass and macronutrient intake in relation to circulating soluble leptin receptor, free leptin index, adiponectin, and resistin concentrations in healthy humans. J Clin Endocrinol Metab 88:1730-1736

12. Nishizawa H, Shimomura I, Kishida K, Maeda N, Kuriyama H, Nagaretani H, Matsuda M, Kondo H, Furuyama N, Kihara S, Nakamura T, Tochino Y, Funahashi 
T, Matsuzawa Y 2002 Androgens decrease plasma adiponectin, an insulin-sensitizing adipocyte-derived protein. Diabetes 51:2734-2741

13. Combs TP, Berg AH, Rajala MW, Klebanov S, Iyengar P, Jimenez-Chillaron JC, Patt ME, Klein SL, Weinstein RS, Scherer PE 2003 Sexual differentiation, pregnancy, calorie restriction, and aging affect the adipocyte-specific secretory protein adiponectin. Diabetes 52:268-276

14. Schmelzle HR, Fusch C 2002 Body fat in neonates and young infants: validation of skinfold thickness versus dual-energy X-ray absorptiometry. Am J Clin Nutr 76:1096-1100

15. Nemet D, Wang P, Funahashi T, Matsuzawa Y, Tanaka S, Engelman L, Cooper DM 2003 Adipocytokines, body composition, and fitness in children. Pediatr Res 53:148 152

16. Yang WS, Lee WJ, Funahashi T, Tanaka S, Matsuzawa Y, Chao CL, Chen CL, Tai TY, Chuang LM 2001 Weight reduction increases plasma levels of an adiposederived anti-inflammatory protein, adiponectin. J Clin Endocrinol Metab 86:38153819

17. Lapillonne A, Braillon P, Claris O, Chatelain PG, Delmas PD, Salle BL 1997 Body composition in appropriate and in small for gestational age infants. Acta Paediatr $86: 196-200$

18. Viengchareun S, Zennaro MC, Pascual-Le Tallec L, Lombes M 2002 Brown adipocytes are novel sites of expression and regulation of adiponectin and resistin. FEBS Lett 532:345-350

19. Moragas A, Toran N 1983 Prenatal development of brown adipose tissue in man. A morphometric and biomathematical study. Biol Neonate 43:80-85

20. Hales CN, Barker DJ, Clark PM, Cox LJ, Fall C, Osmond C, Winter PD 1991 Fetal and infant growth and impaired glucose tolerance at age 64. BMJ 303:1019-1022

21. Lindsay RS, Funahashi T, Hanson RL, Matsuzawa Y, Tanaka S, Tataranni PA, Knowler WC, Krakoff J 2002 Adiponectin and development of type 2 diabetes in the Pima Indian population. Lancet 360:57-58

22. Spranger J, Kroke A, Mohlig M, Bergmann MM, Ristow M, Boeing H, Pfeiffer AF 2003 Adiponectin and protection against type 2 diabetes mellitus. Lancet 361:226228
23. Ogilvy-Stuart AL, Hands SJ, Adcock CJ, Holly JM, Matthews DR, Mohamed-Ali V, Yudkin JS, Wilkinson AR, Dunger DB 1998 Insulin, insulin-like growth factor I (IGF-I), IGF-binding protein-1, growth hormone, and feeding in the newborn. J Clin Endocrinol Metab 83:3550-3557

24. Christou H, Connors JM, Ziotopoulou M, Hatzidakis V, Papathanassoglou E, Ringer SA, Mantzoros CS 2001 Cord blood leptin and insulin-like growth factor levels are independent predictors of fetal growth. J Clin Endocrinol Metab 86:935-938

25. Ong K, Kratzsch J, Kiess W, Costello M, Scott C, Dunger D 2000 Size at birth and cord blood levels of insulin, insulin-like growth factor I (IGF-I), IGF-II, IGF-binding protein-1 (IGFBP-1), IGFBP-3, and the soluble IGF-II/mannose-6-phosphate receptor in term human infants. The ALSPAC Study Team. Avon Longitudinal Study of Pregnancy and Childhood. J Clin Endocrinol Metab 85:4266-4269

26. Bazaes RA, Salazar TE, Pittaluga E, Pena V, Alegria A, Iniguez G, Ong KK, Dunge DB, Mericq MV 2003 Glucose and lipid metabolism in small for gestational age infants at 48 hours of age. Pediatrics 111:804-809

27. Gluckman PD, Cutfield W, Harding JE, Milner D, Jensen E, Woodhall S, Gallaher B, Bauer M, Breier BH 1996 Metabolic consequences of intrauterine growth retardation. Acta Paediatr 417(suppl):3-6

28. Hofman PL, Cutfield WS, Robinson EM, Bergman RN, Menon RK, Sperling MA Gluckman PD 1997 Insulin resistance in short children with intrauterine growth retardation. J Clin Endocrinol Metab 82:402-406

29. Leger J, Levy-Marchal C, Bloch J, Pinet A, Chevenne D, Porquet D, Collin D, Czernichow P 1997 Reduced final height and indications for insulin resistance in 20 year olds born small for gestational age: regional cohort study. BMJ 315:341-347

30. Yamamoto Y, Hirose H, Saito I, Nishikai K, Saruta T 2004 Adiponectin, an adipocyte-derived protein, predicts future insulin resistance: two-year follow-up study in Japanese population. J Clin Endocrinol Metab 89:87-90

31. Cianfarani S, Martinez C, Maiorana A, Scire G, Spadoni GL, Boemi S 2004 Adiponectin levels are reduced in children born small for gestational age and are inversely related to postnatal catch-up growth. J Clin Endocrinol Metab 89:13461351 